\section{ECONOMICS}

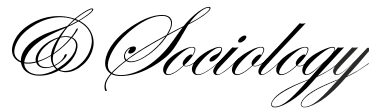

Stamate Andreas, A Private Property Rights Approach on the Social Aspects of a Free Market Economy, Economics \& Sociology, Vol. 5, No 2a, 2012, pp. 100114.

\title{
A PRIVATE PROPERTY RIGHTS APPROACH ON THE SOCIAL ASPECTS OF A FREE MARKET ECONOMY
}

\begin{abstract}
It is often presumed that a free market economy (by this meaning a system in which can be found exclusive private property rights on the means of production) fails at (always) providing social welfare. This is a no-turning point into discussion and it is also a point where the seeds of government intervention seep in. The criterion used for this type of presumptions is what we generally acknowledge as utilitarianism. However, utilitarianism is only one particular criterion from many others, or only one side of the coin. The present paper is focused on the other side of the coin, namely the private property rights criterion (as developed by Murray Rothbard and Hans Hermann Hoppe). Using this analytical and ethical tool, I will try to develop the social character of a free market economy. From the very beginning the paper will summarize the basic elements of free markets. After this, a short journey into the economic and ethical problems of the social welfare concept will prepare the reader for the section where I state the case for a social market economy from a purely private property rights approach.
\end{abstract}

JEL Classification: B53, D6, I3, Keywords: free market economy, private property rights, social $\mathrm{P} 14$ welfare, ethics

\section{Introduction}

The central idea of this paper is that markets fail. They fail in delivering what consumers need, fail in reducing enough prices for different goods and services, fail in stopping anticompetitive practices etc. In a word, they fail. And because they fail, from a social perspective this means that free markets let alone are not the best economic systems for the individuals. They must be somehow regulated by the power of the state. Only this power can ensure equilibrium on the market and can satisfy the needs of the society. Thus government policies can be interpreted as a reaction to the damages that free markets leave behind them, or to those which may occur in the future. This is a rational supposition since they come to substitute a natural state of things, a state where individuals voluntarily cooperate for maximizing their utility. For if all would have been good by having free markets, why should there be any government policies at all?

Although this idea is not a new one, it is nevertheless arguable. It can be found (among 
many others) mainly in the political philosophy of ordoliberalism (affiliated with the FreiburgSchool ${ }^{1}$ ). According to this philosophy, free markets are the best alternatives for allocating resources with only one condition: they must give positive feedback to any state institutions in the name of public good or social welfare. For this reason, the translation of ordoliberalism philosophy into practical political program was baptized as social market economy. Markets must be free, but they also must fulfil society's needs. There is of course, an important issue to discuss here, which for the moment will be resumed to the following question: What elements can possibly exist in the nature of free markets which inflict on fulfilling society's needs?

One may argue that this type of problems can be solved by simply picking up an economic theory which satisfies the interests of the researcher or just offers the most comprehensive answers. But as soon as you pick up the economic theory that you have considered it as the best tool for your analysis, you will discover that it necessarily or implicitly contains some epistemological or methodological suppositions, routed perhaps in the most notorious or, on the contrary, most obscure philosophical theories. For example, when neoclassical economists (Marshall, Samuelson, Baumol etc.) argue that utility functions express a real process with real consumers, they implicitly make the assumption that utility as a concept - can have cardinal magnitudes. In contrast with neoclassical economics, the marginal "revolutionaries" (Menger, Jevons, Walras) had demonstrated that utility refers to individual preferences which are always subjective (cannot be easily observed by an outside observer) and ordinal (I-st is apples, II-nd is cranberries, III-rd is cinema tickets etc.). At stake is the notion of social welfare, which neoclassical economists pretend it can measure, and the marginalists who explain that individual, subjective preferences cannot be summed up to have a social utility or social welfare, because they have a strong psychic component. If the doctrine of social utility (a part of the well-known and more complex concept of utilitarianism) is correct then the social welfare can be measured and translated into any political program. If it is not, this results in some practical consequences, beginning with the legitimacy to use social welfare as a part of public policies. In any case, this is a methodological dilemma, not strictly an economic one, as I have mentioned. It is not sufficient to look only in economic theories. A wider angle of understanding economic problems can be obtained by penetrating their epistemological implications ${ }^{2}$.

One may also argue that ethic arguments should not be considered valid in a scientific discussion. It is true that economic science is neutral as regards value judgments and it should remain as it is. Thus, economically speaking it is improper to say that free markets are good or bad, because these terms have value implications ${ }^{3}$. Free markets are the means for a rational

\footnotetext{
${ }^{1}$ See for example works of Walter Eucken, The Foundations of Economics (Springer, 1992); Franz Böhm, Competition and the Battle against Monopolies (1933) and Ludwig Erhard, Prosperity through Competition (Frederick A. Praeger, New York: 1958).

${ }^{2}$ Other similar works can be found in Ludwig von Mises, Epistemological Problems of Economics (Ludwig von Mises Institute, Third Edition, 2003); idem, Human Action (Yale University Press, 1949), Murray Rothbard, Man, Economy and State with Power and Market (William Volker Fund and D. Van Nostrand,1962); idem Towards a Reconstruction of Utility and Welfare Economics (first published in Mary Sennholz, On Freedom and Free Enterprise: The Economics of Free Enterprise, Princeton, N.J.: Van Nostrand, 1956; reprinted in Murray Rothbard, The Logic of Action One: Money, Method and the Austrian School, London, Edward Elgar, 1997); Joseph Schumpeter, History of Economic Analysis (Allen\&Unwim, London, 1986); Mark Blaug, The Methodology of Economics or How Economists Explain (Cambridge University Press, 1992); more recent in Walter Block, "Realism: Austrian vs. Neoclassical Economics. Reply to Caplan", The Quarterly Journal of Austrian Economics (2003); Walter Block, William Barnett II and Stuart Wood, "Austrian Economics, Neoclassical Economics, Marketing and Finance", The Quarterly Journal of Austrian Economics (2002; Jörg Guido Hülsmann, "A realist approach to equilibrium analysis", The Quarterly Journal of Austrian Economics (2000); idem "Economic Science and Neoclassicism", The Quarterly Journal of Austrian Economics (1999).

${ }^{3}$ See also Murray Rothbard, "Value Implications in Economic Theory", The American Economist (1973),
} 
allocation of resources among individuals who cooperate is a more accurate description. But when government intervention come in, which, as I said, seeks to establish a proper arrangement of resources on the market, as a response to market failures, the discussion takes another turn. By its nature, government intervention is not neutral to values. Therefore, an ethical justification for government intervention is needed. There is also a need of ethical justification in the case of free markets operating, and the present work will tackle it.

All these and much many are problems to discuss for an accurate treatment of the social component of a free market. And it cannot be treated otherwise than opposing it to government intervention because the latter is often in the position to contest free markets. As I have mentioned in the beginning of the introduction, government intervention can be interpreted as a reaction to free markets, either to substitute or to augment their forces. The present paper will focus on few basic epistemological, economic and ethical elements for stating the case for the social character of a free market. The novelty of the chosen theme stems from the decision to combine mostly only two line of reasoning - rothbardian and hoppean - considered to be the fundamentals in economic and ethical analysis within the Austrian School of economics.

The paper is structured in three parts. The first parts deals with the basic elements of a free market. Here I will discuss issues like social cooperation, private property, free trade, the role of money. The second part concerns the nature of government intervention. At this stage, a short analysis of few specific government interventions will take place, such as taxation and redistribution. A greater attention will be given to the theory of social welfare, considered the core element for the justification of government intervention. The third part which is announced in the paper's title is dedicated to the free markets, this time with the purpose of testing its social character.

Needless to say, I do not pretend or claim for the absolute correctness of the statements, either personal or invoked from various writers. After all, the paper is nothing more and nothing less than a trial, and as any trial it is doomed to failure. By this, I have officially opened the road for any remarks or critics in the spirit of the paper.

\section{What are the free markets? A counterfactual exposition}

A historical observation through man actions over time reveals that when he preferred cooperation to conflict he succeeded more properly to satisfy his needs. Conflicts bring poverty, enemies, stagnation while cooperation extends the possibilities for satisfying the needs of individuals. There is of course a sort of welfare from conflicts, but this can be associated only with the winner. By contrast, when individuals cooperate, the welfare is mutually distributed so to speak. Everyone wins and no one loses. A society is compounded of more individuals with various needs and desires. When they decide to cooperate it is in the field of the society where cooperation takes place. Through social cooperation, individuals can also contribute to a more extended division of labour. Every individual can find his best employment in the society by cooperating with other individuals when, of course, this is viewed as a better option than staying in autarchy. A powerful division of labour can improve society's living conditions by placing every factor of production at its best use for the most urgent needs.

In the sphere of human action, social cooperation within the markets always means transfers of different scarce resources, or transfers of welfare. For individuals to transfer an object they must first possess it. They must have property rights. In fact, in a world with scarcity, like Earth, property rights or property titles are, among prices, important vehicles

reprinted in Murray Rothbard, The Logic of Action One. 
which distribute wealth. Without property rights and prices, resources would not benefit of a rational allocation between people. Property rights and prices, in a way of speaking, are synonyms with preservation and rational exploitation of resources.

Ludwig von Mises defines the market economy as:

The social system of the division of labour under private ownership of the means of production. Everybody acts on his own behalf; but everybody's actions aim at the satisfaction of other people's needs as well as at the satisfaction of his own (Mises, 1998, p. 258).

But why markets, where individuals exchange property titles, have to be free? How else could they be? Well, if we refer to Franz Oppenheimer's description concerning the means of acquiring wealth in a society, we will understand that only two means can be imagined: economic means and political means. (Oppenheimer, 1922) Oppenheimer describes the first as the means through which individuals voluntarily or freely exchange property titles, and the latter as those which use violence for acquiring property titles (under the incidence of a conflict). From this description we understand that within markets individuals can make use of the economic means, the political means or a combination between the two. We also understand that by using the political means, individuals extend the sphere of violence or aggression and reduce the sphere of liberty in the society. Violence or aggression is opposed to liberty, and these are not relativistic, abstract notions. As we have seen in the beginning of this part, liberty in the sphere of social cooperation can increase welfare by making every individual better off. Many things can be said if individuals prefer conflict to cooperation, but perhaps it is difficult if not impossible to argue for a unanimous welfare. Here is how Murray Rothbard describes the free market:

The network of voluntary interpersonal exchanges forms a society; it also forms a pattern of interrelations known as the market. A society formed solely by the market has an unhampered interference of violent action. A society based on voluntary exchanges is called a contractual society...In a contractual society, each individual benefits by the exchange contract that he makes (Rothbard, 2004, pp. 90-91).

For instance, when we speak about free trade, we understand first, a property title and second, a contractual transfer of it to that individual who requested it. From this point of view, free trade is compatible with a society where individuals prefer, in the oppenheimerian sense, the economic means. It is important to mention that free trade can also be compatible (in a very narrow sense) with a society where individuals prefer the political means. Thus it becomes crucial important to distinguish the property titles acquired through the economic means from those acquired through political means.

In a society which benefits from the extended division of labour, individuals tend to use some goods not for their specific use in various activities but for their exchange value. These goods become more marketable and soon take the role of a medium of exchange. They are called money. The function of money is to enable an easier process for distributing property titles. The buyer can find the seller more easily, and vice versa. Money also improves - in the sense of extension - the capital goods structure. By having an extended capital goods structure there can be developed many ways for satisfying the same need. Money - as any other good freely exchanged between individuals - have prices. The prices of money follow the same logic as in the case of oranges, peas or flowers. The demand for money meets the supply of money in a point where transactions are completed. The decisions to buy and sell are always made by marginal actors (buyers and sellers) and the final price always reflects the 
scarcity of money.

On money prices and prices in general, people make different assumptions. For instance, in the scholastic literature of XVI, XVII and XVIII centuries an entire debate concerning the nature of prices and their justness can be found. Spanish thinkers like Juan de Mariana or Luís de Molina, members of the Jesuit order are good liberal examples, who advocated among many other things, also against coinage debasement and price controls (Rothbard, 2006, pp. 114-120). The debate with regard to just prices can be even traced back to medieval economic thought in XI and XII centuries, as expressed by some prolific thinkers such as Thomas Aquinasaccording to which the just price is any market price (Rothbard, 2006, p. 50). If we return to this literature we will discover that the just price issue is always discussed in connection with the moral laws of the church, especially regarding usury. Today, concepts like just prices or just allocation are very well internalized by competition authorities in different countries. These are responsible for implementing the competition policy as dictated by the interests of the state. Although we can find them in the elaboration of policies and law texts, it is important to state that there is no consensus among their formulation. They often describe sterile notions such as social justness or the justness of the many, these having strong methodological and ethical implications.

In the contractual society or free market economy, defined as the society based on freedom in exchanging property titles, individuals act in accordance with their contractual rights and duties. Private property on the means of production guarantees to the entrepreneurs that they can involve in profitable exchanges. If profit is obtained, then entrepreneurs are well connected to the consumers. Through economic calculus they can distinguish between the most and the least urgent projects. By acting in this way they are strongly stimulated to always listen to what the consumers have to say. Thus, good efforts in the right direction (satisfying the consumer) receive the important "prize" (profit) while bad efforts (noncompliance with the will of the consumer) prepare the path towards bankruptcy.

\section{The nature of government intervention}

Government intervention will be treated as the factual component of the exposition. It means that while describing government intervention, reality corresponds to this description. Government intervention or the factual component is of course, an opposite to the counterfactual component, detailed in the first part of the paper. The description concerning free markets was the pure theory and it is counterfactual because it presents a state of things which cannot be totally observed in reality. Government intervention is the actual state of things, but it can be understood only if we put it in contrast to its opposite (Hülsmann, 2003). As I have mentioned, it can be regarded as a reaction to a state of things - free markets which did not succeed in accomplishing its mission. It will be the task of the third part of the paper to explain if this reaction is correct, or on the contrary, if it contains errors.

According to Oppenheimer, the state or the government (at a reduced scale) is the organization of political means. Its resources are not voluntarily appropriated on the market, but by the use of violence. The proof of violence stems from the fact that there is no clear, objective consensus between the state and the parties involved. But to understand Oppenheimer's description of the state, I must first emphasize the theory with the help of which I will explain the nature of government intervention. It is the theorem of nonaggression, as formulated by the libertarian thinker Murray Rothbard, and it presumes the following:

No man or group of men may aggress against the person or property of anyone else. This may be called the "nonaggression axiom." "Aggression" is defined as the 
initiation of the use or threat of physical violence against the person or property of anyone else. Aggression is therefore synonymous with invasion (Rothbard, 2006, p. 27).

Thus, the state is the only organization that can appropriate its resources not by consensus, by the law of demand and supply on the market, but by initiation of aggression and the use of violence against property owners. A representative example is the act of taxation, a basic activity through which all states finance their operations. Hans Hermann Hoppe, one of the disciples of Rothbard regards the act of taxation, a mean to expand the field of unproductive activity in the society. Because states always tax citizens who produce for the society, a rise in percentage of taxation will necessarily lead to an increase in the number of unproductive areas and a decrease in those who are forced to finance the first, the productive ones.

Introducing or raising taxation thus implies that monetary income flowing from production is reduced for the producer and increased for people in their roles as nonproducers and noncontractors (Hoppe, 2010, p. 64).

By redistributing the taxed resources, states continue to subsidize the area of nonproducers on the expense of producers.

Any redistribution of tax money is a transfer from monetary income producers and contractual money recipients to people in their capacity as nonproducers and nonrecipients of contractual money incomes (Hoppe, 2010, p. 64).

One would argue that, although everyone is paying taxes to the state, the same everyone benefits of different services which the state finance with the taxed resources. Against this thesis the following arguments have been brought by Rothbard, who is citing John C. Calhoun:

The necessary result, then, of the unequal fiscal action of the government is to divide the community into two great classes: one consisting of those who, in reality, pay the taxes and, of course, bear exclusively the burden of supporting the government; and the other, of those who are the recipients of their proceeds through disbursements, and who are, in fact, supported by the government; or, in fewer words, to divide it into taxpayers and tax-consumers (Rothbard, 2006, pp. 64-65).

It is not the case here to detail the saga of specific government policies. For the moment it is sufficient to mention that, when the market is regulated by different government interventions, regardless the purpose of these interventions, some changes in the individuals' behaviour takes place. Both entrepreneurs and consumers will focus rather on the incentives resulted from government intervention than on those from free market. Entrepreneurs will first engage in different strategies to anticipate or avoid the effects of intervention and only after, in making profit recte satisfying the consumer. This shift in their preoccupation can cause errors in allocation and anticipation of the real needs of the consumers. The efficient entrepreneurs who satisfy the needs of the consumers are penalized while those who are inefficient (were not capable before intervention to meet the needs of the consumers) are now competing with the formers.

In a society based on government intervention, there is clearly a group of individuals who are net receivers of taxes, or tax-consumers. More taxes mean less productive activity or at least a strong incentive for individuals not to involve in productive activity (which has increasingly high costs) but in those areas where they can receive (more) taxes. More taxes 
also mean a disincentive to work, because the monetary income is less than the costs associated with the work.

If individuals realize that they can appropriate resources more easily by unproductive activity (politics, public projects where there is a high risk of corruption etc.) they will leave the sphere of production.

If people have an interest in stabilizing and, if possible, increasing their income and they can shift relatively easily from the role of a user producer or contractor into that of a nonuser, nonproducer, or noncontractor-assumptions, to be sure, whose validity can hardly be disputed - then, responding to the shift in the incentive structure affected by socialization, people will increasingly engage in nonproductive and noncontractual activities and, as time goes on, their personalities will be changed (Hoppe, 2010, p. 45).

And socialization is put in practice every time when governments enforce taxation. The more government enforce taxation the more socialized property (monetary) exists. And the more socialized property exists the smaller are the chances for a rational allocation of resources. Therefore any government is somehow trapped in a situation where only two rational measures are possible: either raising taxes or keeping them at the present level. Any reduction in taxes would create a social discomfort for those who benefited from taxes and they will plea for keeping them.

\section{The social character of free markets}

As it was stated in the introduction, the present paper deals with the common critique that free markets fail. They are not socially enough, so to speak. The purpose of this last part of the paper is to demonstrate the contrary. Free markets meet all the requirements to be considered socially responsible ${ }^{4}$. Moreover, with the help of economic and ethical arguments which we cannot avoid, it will be asserted that it is government or the state in general the entity who fails in creating social welfare. But before the demonstration, few notifications must be made. The first concerns the use of the term social or society. It must be emphasized that society is compounded of many individuals who have different needs. When we refer to society we implicitly refer in particular to every individual, member of the society. According to the praxeological theory of human action developed by Ludwig von Mises, society is not something separated of individuals. Society does not act, as individuals do and we cannot speak about society's needs, views or welfare because this would mean to sum up things which by their nature cannot be summed up. Thus, we refer to society as a convention, but totally aware of the fact that it is composed of different people. It is important how we regard the society, conceptually and practically too, since our views can be translated as time passes into political views. The political doctrines of our times must necessarily be acknowledged and approved by the members of the society. Their major components always reflect how people regard to various specific issues such as democracy, justice, social welfare etc.

Arnold W. Green has recently demonstrated how the use of invalid collective concepts has damaged the discipline of sociology. He notes the increasing use of "society" as an entity which thinks, feels and acts, and, in recent years, has functioned as the perpetrator of all social ills...In many quarters "society" is considered almost demonic, a "reified villain"

\footnotetext{
${ }^{4}$ Where social responsibility means delivering useful goods and services to the members of the society, the indiv iduals. There is no connection between Corporate Social Responsibility (CSR) and the term social responsible us ed in the present paper.
} 
which "may be attacked at will, blamed at random, derided and mocked with selfrighteous fury [and] may even be overturned by fiat or utopian yearning - and somehow, in some way, buses will still run on time" (Rothbard, 1997, p. 54).

The second notification refers to how the personification of society and the errors of utilitarianism have penetrated the economic science and gave birth to methodological errors. The most notorious is the attempt to measure social utility or social welfare, not paying attention to the fact that individuals have different preferences and these are only ordinal, not cardinal so as to allow a process of quantification. (Mises, 1912; Robbins, 1932).

If I buy a newspaper, all that can be known is that my utility from the newspaper is greater than from the fifteen cents, and vice versa for the news dealer. There is no way of measuring these utility gains, for utility is not a quantity, but a rank of subjective valuation (Rothbard, 1997, p. 259).

By pretending the possibility of measuring social utility (Samuelson, 1937; Lange, 1942), the intention was, of course, to give legitimacy to government intervention when it was necessary. As long as we have the "index" of social utility any public policy can be implemented in the name of its "costless operations". More or less similar to this attempt were the Pareto's Unanimity rule, the Compensation Principle, Cost-benefit analysis. Even some of the moderate supporters of social utility functions proved to be sceptical with regard to measuring utility.

In the form in which the question of measurable utility arises in this place, it is completely disposed of by the classical demonstration of Pareto: that the ordering of the sets...does not suffice to determine a single Utility function. The single 'product', utility is a mere construct; it is inadequately defined to be an object of measurement. The idea of measuring utility, or welfare, as such, is a blind alley (John Hicks cited by John S. Chipman in Hagemann and Hamouda, 1994, p. 102).

If we contemplate these two notifications which accommodate the major views on social welfare and utility, an important question can be raised: if there is no such thing as social welfare then to whom it refers the advocates of this doctrine? It was stated that society means taking into consideration all the individuals. It was also exposed how welfare is a concept specific only to individuals, that it can be correctly used only in connection with the social preferences of individuals taken separately, not aggregately. It can be no aggregate social welfare because individual preferences (based on utility functions) cannot be measured, given their ordinal character.

For answering the above question we must be aware of the fact that government intervention on the basis of social utility is not neutral. By this it is understood that it has redistributive effects. It must necessarily discriminate between individuals or classes of individuals. As in the case of taxation so in any other case, government must plea for the relative importance of tax consumers when taxing everybody else. Those who consume taxes are much more important - at least at the present moment - than those who pay taxes. When a bridge or highway is constructed, the government delivers it as socially useful, but in fact, to make it possible it had to tax other people. A strong component of this discussion is also the effective cost of government goods, in which enters remuneration for those who work to produce them.

When the government decides to eliminate the subsidies for sector A so as to finance, let's say the education system, again it discriminates between the importance of individuals who work in sector A (considered smaller) and that of the individuals from the educational 
system (considered greater). This inherent discrimination specific to any government action, leads to the conclusion that whenever a government intervention takes place it is not the whole society who benefits but few groups of people. The implications are the following: any government intervention must necessarily increase the utility or welfare of one group of individuals on the expense of another. Thus whoever refers to any type of government intervention must be aware of the fact that it is not the society who benefits of it but few groups. And the crucial thing for the people is how to be a part of these groups. Few clarifications should be set in here. First is that I use the term "discriminate" not to prove what was already proven by many writers - that governments have to take, in the first, for then to give - but to explicitly show that it is a discrimination which does not possess rational or objective criteria. This being clear, it implies, in the second, that any government act is confronted with two basic problems or questions: (1) how extended should be the supposed intervention and (2) who should finance it?. I adapted the questions after Rothbard (1997) where he explains the problem within the sphere of taxation.

A common reasoning is that government intervention is necessary for the creation of some kind of public goods or services, which supposedly, free markets wouldn't be able to deliver. Moreover, it is asserted that government should be an entity responsible with problems such as people with disabilities, children or elderly people. With regard to the theory of public goods, it must be stated that from an economic point of view, any good or service is subject to the law of supply and demand. Thus, the only logical interpretation of the public goods is that they refer to the quality of being free to be sold and bought by all the individuals, not being produced by a special agency (Molinari, 1977; Hoppe, 1989). As concerns the default-tasks of government in the sphere of charity, there are many studies ${ }^{5}$ who explain that private charity cannot be substituted by government. First, it is the problem of consistency, for it cannot be pretended as being possible to improve the welfare of some people or of the society by hurting ${ }^{6}$ other people. It can hardly be constructed a case for the economic efficiency and ethical consistency of Robin Hood 'actions, although - prima facie some people receive net welfare. To some extent, this is a similar discussion with that of the great French economist Frédéric Bastiat (1801-1850), who distinguished within acts of government between what is seen and what is not seen (also known in economic literature as the broken window fallacy). Following his reasoning, what is seen is the net welfare received by the poor or unproductive people and what is not seen is the welfare taken from the rich or productive people; the latter - the welfare taken - can be translated in jobs, goods, services that could be produced on the market. Second, the so called government charity must necessarily reduce the goods and services available for private charity, and again cannot be viewed as an improvement of the social welfare.

But of course, the discussion can go further, on ethical grounds. In the end, to support government intervention one must necessarily presume that what few groups receive is of net importance than what others are deprived of. This sort of ethics is incoherent if we follow the basic Aristotelian principle of universality. Any ethical principle or science of ethics must refer to all people (universal) otherwise is incomplete or incoherent. To support the bridge

\footnotetext{
${ }^{5}$ See Ludwig von Mises, The Anti-Capitalistic Mentality (Princeton, N.J.: Van Nostrand, 1956); F.A. Harper, The Greatest Economic Charity (essay published in On Freedom and Free Enterprise. Essays on Honor of Ludwig von Mises, Mary Sennholz, Princeton, N.J.: Van Nostrand, 1956); Henry Hazlitt, The Conquest of Poverty (New Rochelle, NY: Arlington House, 1973); David T. Beito, From Mutual Aid to the Welfare State: Fraternal Societies and Social Services, 1890-1967 (Chapel Hill, University of North Carolina Press, 2000); Arthur Brooks, Who Really Cares: The Surprising Truth about Compassionate Conservatism (Basic Books, 2007).

${ }^{6}$ On the non-consensual relationship between states and individuals see Herbert Spencer, The Man versus the State (Indianapolis IN, Liberty Fund, Inc., 1992);Anthony de Jasay, The State (Liberty Fund, 1998);Murray Rothbard, The Ethics of Liberty (New York University Press, 1998); idem, The Anatomy of the State (Ludwig von Mises Institute, 2009).
} 
construction one must be aware of the amount of money some tax payers are deprived of and, most important, must view this act as a legitimate one. Similar to this, to support minimum wage laws ${ }^{7}$ implies to view as a legitimate act leaving a number of people out of jobs for the benefit of some other people (Rothbard, 2004).

The plea for the social character of free markets will follow the libertarian theorem of non-aggression (on ethical grounds) for its ethical coherence and few economic arguments in the tradition of the Austrian School of economics.

Free markets mean the absence of aggression from external factors. As we could observe in the second part of the paper, government or the state in general is the prime source of aggression in society. Society - understood now as all individuals - benefits whenever there is voluntary cooperation on the market, or when the market is free. In this way, they can satisfy their needs properly. For instance, free markets develop what in economic science we call a criterion for the rational allocation of resources. These are the prices. Through prices, which always reflect the scarcity of goods, we are informed that everything on this planet must be rational exploited. And prices make possible the process of economic calculation. More exactly monetary prices. Economic calculus is the guiding force when entrepreneurs evaluate between different business projects. The prospect of profit will determine investments and the prospect of losses will leave off those projects in other hands, better equipped. On the free market, entrepreneurs are determined to invest in those projects which can maximize their profit. This task can be accomplished only in relation with the consumers. It is always the consumer in the centre of economic activity. By virtue of his will, entrepreneurs develop and innovate. It is demand which determines the supply and not otherwise. Or, contrary to Marxism, first is demand or consumption then supply or production. No good can be brought on the market by not being first demanded by consumers. Thus, more or less, the structure of production at a given point in time must reflect consumers' preferences. If we view the market in this way, we can easily conclude that it definitely has a social character, because tends to satisfy social preferences, or individual preferences. Furthermore, in a free market, every people receive strong incentive to specialize and to become an important piece in the big puzzle of the division of labour. Specialization means delivering useful goods and services to the society. People are enjoying the fruits of their labour according to their level of specialization. Nevertheless, free markets are not an absolute alternative. Even when all the conditions of development are met, there can still be some people who cannot find their place, unsatisfied of different issues or just frustrated by the fact that development and welfare takes time and persuasiveness. There will always be few unsatisfied. The essential thing is that they have the basic conditions to succeed on their own.

When government enters the picture free markets disappear or are just diluted, so to speak. Government or the state is, as Hans Hermann Hoppe put it, a territorial monopoly on aggression. Usually ruled by a small group of people, the state, in order to survive, must tax its citizens. This means that it makes use of force or violence to attain its ends. Taxes reduce the monetary income of the people, fact which can lead to less investments and innovation, extremely negative for the society. By having reduced the monetary income people can also have a disincentive to work. Economic calculation and profit become difficult operations and people tend to specialize in those activities where they can earn a living more easily. More and more people will wish to become members of the community which redistribute the taxed money ${ }^{8}$ or which simply contrive new taxes. A strong incentive will occur then to engage

\footnotetext{
${ }^{7}$ See William H. Hutt, The Theory of Collective Bargaining (Free Press, 1954), Sylvester Petro, The Labor Policy of the Free Society (The Ronald Press Company New York, 1957).

${ }^{8}$ See the "wave" of European projects ("structural funds") which redistribute the taxed money, especially from $t$ hose countries with the higher growth rates.
} 
rather in public projects or even politics, where easy earnings can be made in a short period of time than to enter in the field of production, to satisfy consumers 'needs. The field of production has now high costs.

In the following, we will take two examples in order to explain what kind of changes brings government intervention into the nature of economic activity and structure of incentives on the market.

\section{The production of money}

The most regulated sphere of activity in the present day society is the monetary one. The official view is that money must be produced by the state, the only entity which can certify for the quality of money and also which can counteract any fraud. The present day consequences of this state of things are fiat money, or money from nothing ${ }^{9}$. Having no natural constraints (like in the case of gold) central banks can print paper money whenever it is in the interest of the state (Păun and Topan, 2011). But is it also in the interest of individuals? Or, can ever central banks be social responsible institutions? They can hardly be considered like that. There are also studies which argue for the utopian character of the political independence of central banks (Hülsmann, 2008, p. 168; Bagus, 2010, p. 33; Mușetescu, 2012). Central banks together with commercial banks put in practice a banking system based on fractional reserves ${ }^{10}$. Fractional reserve banking is a banking system which allows the commercial banks not to hold $100 \%$ of their reserves, but to borrow money received as savings accounts (demand deposits) which depositors can withdraw anytime. The system is officially approved by the institution of the central bank. This system allows an unfortunate expansion of the money supply which raises prices on the market (inflation) and determines business investments which otherwise would not have been feasible because the society has not saved enough for them (Rothbard, 2005, p. 44). When inflation is created, a sort of redistribution process takes place on the hampered market. As prices don't go up very fast, those who are creating the artificial money (central and commercial banks) will not be affected by the increase in prices, thus being able to buy more goods and services with the new money. Prices increase slowly affecting the downstream of the economy, the greater majority of the people, who will discover that their purchasing power was diminished. After prices increase they will buy less goods and services with the same amount of money. A transfer of wealth (Cantillon effect) is thus taking place, from the downstream of the economy where we find most of the people and small businesses to the upstream represented by the central and commercial banks. Again, it is some groups which benefit on the expense of another. Whoever supports monetary systems based on fractional reserves or central banks which arbitrarily downsize the rate of interest must regard this forced transfer of wealth as unproblematic. Anyhow, it cannot be argued that society benefits. On a free market, with private production of money and competition between different money, no entity can create artificial money on a long term. The competition will discover this and will get rid of it (Rothbard, 2005, pp. 23-24). On a free market no entity can have an absolute monopoly on money production. Being free entrance in the field, there are natural incentives for preserving the value and quality of the money employed in transactions. The economic consequences of centralized money production can be seen especially when the crisis occur ${ }^{11}$. It is the moment

\footnotetext{
${ }^{9}$ On the problem of fiat money see Hans Hermann Hoppe, "How Is Fiat Money Possible - or, The Devolution of Money and Credit", The Review of Austrian Economics (Vol.7, No.2, 1994).

${ }^{10}$. For further reading see Murray Rothbard, The Mystery of Banking (Ludwig von Mises Institute, 2008); Jesús Huerta de Soto, "A Critical Analysis of Central Banks and Fractional-Reserve Free Banking from the Austrian S chool Perspective", The Review of Austrian Economics (Vol.8, No.2, 1995).

${ }^{11}$ For a detailed analysis of unsound policies to counteract the effects of financial and economic crisis see Păun,
} 
when big projects, sponsored by the artificial stock of money, have to go bankrupt, fact which determines an increase in the rate of unemployment. The ethical implications of centralized money production and inflation are revealed in time, as the illicit transfer of wealth's process is put in place (Hülsmann, 2008, p. 100). Although it is an obvious aggression because it inflicts on the private property rights of people, inflation starts to be a modus vivendi for the central banks.

\section{Competition}

Government intervention in the sphere of competition resulted in laws and regulations put in practice by resort authorities (e.g. competition council) to protect the market and consumers of different business practices ${ }^{12}$. According to these, monopoly, oligopoly and cartel are the most notorious faces which competition between companies can take and which must be penalized because they bring a loss in social welfare and efficiency. Microsoft Corp., Saint-Gobain or Unilever ${ }^{13}$ are few study cases, extremely relevant for the case of competition. Together they paid more than $3 \mathrm{bn}$. Euro fines to the European Commission for being disloyal to competition and consumers. However, from an economic point of view, the size of a firm is not relevant. What is important is if a firm succeeds in satisfying the needs of the consumers, whatever those needs may be. Either we deal with one big firm, or an association between few or many firms the relevant issue in question is whether or not they respond to the various needs of the consumers. Thus any form the market would take, if it is unhampered by external factors (such as government regulations), it must be a form generally accepted by the consumers. Microsoft would not be Microsoft if the American and European consumers wouldn't have been approved it as the best producer - for the moment - of operating systems. Saint-Gobain would not be Saint-Gobain if the European car owners wouldn't have been buy cars equipped with Saint-Gobain car glass (Stamate, 2011; Stamate, 2011a). The size or the number of the firms specialized in satisfying the needs of the consumers are again not relevant. The fact that consumers bought Windows and Saint Gobain car glass is, economically speaking, the burden of proof that they prefer those goods against others. And the demonstrated preference of the consumers is perhaps a very well scientific founded fact (Rothbard, 1997) But the actual laws and regulation do not follow these basic logical and economic principles. They proceed to penalize lots of firms on the market for improper satisfying the needs of their consumers, being interested more in ambiguous and arbitrary concepts such as consumer welfare or loss in social welfare. By acting in this way, competition authorities declare war to some efficient firms, and prepare the entrance for some other firms which would have not been able otherwise to enter the market.

Perhaps one of the most obvious shortcomings of the legal texts which regulate competition is that they do not accept the distinction between economic monopolies and cartels and those determined by the legal framework. Economic monopolies and cartels are subject to the same laws of supply and demand and their capacity to manipulate prices or outputs is depended of the will of the consumer. If this is not true, then economic laws are simply empty speech. Legal monopolies do not dependent in any measure of the will of the consumer. They are defined by law and their output's prices are set according to the same law, often being a

C. and Topan, V. (2012), "Sound and Unsound Public Policies Addressed to Crisis of Modern Financial Systems”, Athens: ATINER'S Conference Paper Series, No:ECO2012-0324.

${ }^{12}$ The most notorious successful attempts to regulate economic competition are the Sherman Act adopted by the US Congress in 1890 and the Treaty of Rome's (1957) legal provisions on European competition embodied in Article 101 and 102.

${ }^{13}$ The statements of objections and decisions for these cases are available at http://ec.europa.eu/competition/inde x_en.html 
result of political negotiations. From this it stems a lot of errors in defining the market and competition in general. For instance, there are countries where the market size of the firm or their market shares is legally enforced on the presumption that above these sizes or shares, firms would become - almost unequivocal - abusers, taking advantage of the consumers by reducing outputs and increasing prices. For instance, the Romanian competition law states that:

Until evidence to the contrary... an undertaking or a group of undertakings are in a dominant position if their market share or aggregate market shares on the relevant market, in the period under analysis, exceed(s) 40\% (CC, 1996).

Economic logic should be sufficient to state that as long as the market is free, any other firms could compete with these so called abusers. Competition policy is in the first place a matter of economics and thus should be subject more to the rule of reason than the rule of law (Mușetescu and Stamate, 2011).

The economic effects of government intervention in competition can determine a shortage of goods and services on the market which is absolutely not a social responsible action. Also, intervention can determine some of the efficient entrepreneurs to leave the market thus reducing the level and concentration of competition, which is exactly the opposite effect of what competition state laws declare. Needless to say that, under the protection of ambiguous laws and regulations, some entrepreneurs (especially those who were not able to compete on the free market) can raise prices not as a reaction to consumer demand, but as a proof of their political dominance over the consumer. Some other important changes can occur on a market where competition is regulated by government. Whenever state laws institute a monopoly - in our case, a monopoly on the definition of competition and on the power of aggression against those who avoid the official accepted definition - people or entrepreneurs tend to organize themselves so as to impose their personal views on how competition should take place. This opens the path for any unsatisfied or frustrated competitor to make proposals of laws and regulations which can stop or at least diminish the power of the most efficient ones, those who proved to be the best for their consumers. In this way, as Gresham's law stipulates in the monetary sphere, the place of efficient and consumer oriented entrepreneurs will be taken by some inefficient ones, determining a loss for consumers.

On ethical grounds it is the question of justness. Is it just to penalize entrepreneurs who won their place on the market as best servers of the consumer 'needs? If we follow the economic reasoning and the libertarian theorem of non-aggression we can state that there is no justness in these state laws and regulations. To penalize the entrepreneurs in the name of some ambiguous concepts is to enforce aggression on their private property rights.

\section{Conclusions}

The purpose of the present work was to expose few economic and ethical arguments against the thesis that free markets let alone fail or that, they are not sufficiently delivering social welfare. The ethical arguments embodied the libertarian theorem of non-aggression. Any individual is free to cooperate with others as long as it is a voluntary cooperation, or no one makes use of violence to attain its ends. In other words, no one aggresses on the private property rights of others.

The first and the most important conclusion was that government intervention is not neutral, in that it has implicit ethical values. To support government in its actions implicitly means an adherence to these values which are incoherent and inconsistent. The cause is that they are not universal or valid for every man (taxation and redistribution were the examples treated).And if the society is composed of all individuals, it logically follows that government 
intervention cannot be social or socially-oriented. Government intervention necessarily improves the position of some groups of people on the expense of other groups. To hold the ethical incoherent character of government intervention it was important to explain first the methodological problems behind the concept of social welfare or social utility. Thus the paper brought the main arguments against the pretence of neoclassical economics concerning the possibility of measuring utility. Having no methodological option to measure welfare or utility it followed that neither interpersonal comparison of utility nor aggregating it are legitimate actions. It also followed that, taking into account the inexistence of a practical aggregate welfare, any government intervention (by default, non consensual) must arbitrarily discriminate between different groups of people. Some people are net payers for the government and some net receivers. On a long term, the structure of the society can change. More people can become interested in extract other people's welfare, as long as the governmental tool permits it. If earnings can be made more easily by political lobby than by honest efforts on the market, people will tend to lobby.

A second conclusion came on the pure theoretical ground of free markets. On the free market every individual strives to occupy the best position. If he is an entrepreneur, in making profit he is determined to always look for the consumer. The most efficient entrepreneurs receive the biggest profit and the happiest and satisfied consumers. Thus free markets have a strong social component in the sense that every private act tends to maximize the profit or at least to minimize the losses. The existence of private property and economic calculus creates an economic playing field where entrepreneurs (either monopolists or cartelists) are constrained to satisfy social needs or consumer's needs.

The third and the last conclusion can be interpreted as a sort of empirical proof of government failure in creating social welfare, in making everybody better off or at least leaving no one worse off. A short description of the nature of modern banking showed how inflation operates a fraudulent redistribution process from an ethical perspective. And whatever is termed fraud fails to be social. Also, the intervention of state competition authorities in the process of competition was proven to harm both the entrepreneurs and the consumers. Moreover, this can alter the nature of incentives and economic calculus, making firms more interested in proposing laws and regulations that exclude other competitors. In short, it is this dilemma: Who can plea for the inoffensive character of the competition law?! Avoiding that on a free market only consumers allow for monopoly, oligopoly or cartels, competition authorities started to penalize normal business practices. This literary determines a mutilation of the market, where efficiency is thrown out and desired goods and services become scarce.

\section{References}

Bagus, Philipp (2010), The Tragedy of the Euro, Ludwig von Mises Institute, Auburn, Alabama.

Hagemann, H., Hamouda, O.F. (1994), The Legacy of Hicks. His Contributions to Economic Analysis, Routledge, 2 Park Square, Milton Park, Abingdon, Oxon, 1994.

Hoppe, Hans Hermann (2012), A Theory of Socialism and Capitalism, Ludwig von Mises Institute, Auburn, Alabama.

Hoppe, Hans Hermann (1989), Fallacies of the Public Goods Theory and the Production of Security, Journal of Libertarian Studies, Vol. IX, No. 1.

Hülsmann, Jörg Guido (2008), The Ethics of Money Production, Ludwig von Mises Institute, Auburn, Alabama.

Hülsmann, Jörg Guido (2003), Facts and Counterfactuals in Economic Law, Journal of Libertarian Studies, Vol. 17, No. 1, pp. 57-102. 
Lange, Oscar (1942), The Foundations of Welfare Economics, Econometrica, Vol. 10, No. 3/4, pp. 215-228.

Mises, Ludwig von (1998), Human Action. A Treatise on Economics, Ludwig von Mises Institute, Auburn, Alabama.

Mises, Ludwig von (1912), Theory of Money and Credit, Indianapolis: Liberty Classics.

Molinari, Gustave (1977), The Production of Security, The Center for Libertarian Studies, New York.

Mușetescu, Radu Cristian (2012), Central Banks'independence and monetary competition: Why the Euro should grow stronger as compared to the US dollar, Revista Oeconomica, No. 4.

Mușetescu, R., Stamate A. (2011), Formal Rules versus an Economic Approach in Dealing with Cartels: the Need for More Coherence in European Competition Law, Romanian Journal of Foreign Affairs, Vol. 11, No. 4.

Oppenheimer, Franz (1922), The State. Its History and Development viewed Sociologically, New York, Vanguard Press.

Păun, C., Topan, V. (2011), Gold Standard: net costs or net benefits for modern economies?, International Journal of Public Law and Policy, Vol. 1, No. 3, pp. 309-320.

Romanian Competition Council, Romanian Competition Law, available at http://www.consiliulconcurentei.ro/uploads/docs/concurenta/LEGEA_CONCURENTEI_Nr_ 21_eng_rev_1.pdf).

Robbins, Lionel (1932), An Essay on the Nature and Significance of Economic Science, New York: New York University Press.

Rothbard, Murray N. (2004), Man, Economy and State. Power and Market, Ludwig von Mises Institute, Auburn, Alabama.

Rothbard, Murray N. (2006), For a New Liberty, Ludwig von Mises Institute, Auburn, Alabama.

Rothbard, Murray N. (1997), The Logic of Action. London: Edward Elgar.

Rothbard, Murray N. (2005), What has the Government done to Our Money, Ludwig von Mises Institute, Auburn, Alabama.

Rothbard, Murray N. (2006), An Austrian Perspective on the History of Economic Thought. Economic Thought Before Adam Smith, Ludwig von Mises Institute, Auburn, Alabama.

Samuelson, Paul (1958), Economics: An Introductory Analysis, McGraw-Hill Book Company, Inc. New York, Toronto, London.

Samuelson, Paul (1937), A Note on Measurement Utility, The Review of Economic Studies, Vol. 4, No. 2, pp. 155-161.

Stamate, Andreas (2011), Towards a Reconstruction of Microsoft vs. European Commission Dispute Using the Theory of Free Competition, Journal of Academic Research in Economics, Vol. 3, No. 2, pp. 219-232.

Stamate, Andreas (2011a), Free Competition Theory and the Secret Agreements between Companies. Saint-Gobain Under the Charges of Cartel, Romanian Journal of Economics, Vol. 33, Issue 2. 